\title{
O sacrifício e o Pathos Divino Aproximações entre René Girard e Jürgen Moltmann
}

\author{
Orientadora: Maria Clara Lucchetti Bingemer \\ Mestrando: Sidnei José da Silva \\ Área de Concentração: Teologia Sistemático-Pastoral \\ Linha de Pesquisa: Religião e Modernidade \\ Projeto de Pesquisa: A experiência do divino nas religiões do Livro
}

O sacrifício e o pathos divino, aproximações entre René Girard e Jürgen Moltamnn se inscreve entre as férteis articulações interdisciplinares da teologia deste tempo aberto e sensível ao falar de Deus na contemporaneidade. As pistas deixadas pela estranha relação entre a violência e a religião, que haviam inquietado de longa data a etnologia, mas que recentemente arrefeceram-se com respostas esparsas, receberam novo fôlego através das obras de Girard. Partindo da mesma chave hermenêutica sacrificial, mas usando categorias epistemológicas distintas, o pensamento de Girard e a teologia de Moltmann se fundem, demonstrando a inusitada unidade testemunhal dos Evangelhos como complementação definitiva da narrativa da história salvífica e demonstração plena do pathos de Deus em favor de toda a humanidade. Isso se deve não simplesmente porque o Crucificado esteja vindicado e inscrito na atrocidade e violência dissimulada, mas exatamente por ser ele a vítima menos provável de toda a história.

Palavras-chave: Sacrifício. Vítima. Pathos Divino. 